This item is the archived peer-reviewed author-version of:

Impact of different sources of credit in creating extreme farmer distress in India

\title{
Reference:
}

Pandey Bhavna, Bandyopadhyay Prabir, Guiette Alain.- Impact of different sources of credit in creating extreme farmer distress in India Benchmarking - ISSN 1463-5771 - (2019), p. 1-16

Full text (Publisher's DOI): https://doi.org/10.1108/BIJ-10-2018-0321 


\title{
Impact of different sources of credit in creating extreme farmer distress in India
}

\author{
1. Introduction \\ "India's agricultural sector is at a crossroads, facing challenges of stagnation in crop yields, \\ non-remunerative prices, falling crop incomes and tardy responses from public service \\ systems."- (Kannan 2015)
}

The problem of farmer suicides, also known as the Agrarian crisis is the rampant phenomenon of suicides among Indian farmers from the year1990 to the present. It has been exacerbated by the inability to repay growing debt, often taken from local moneylenders. In this paper, we situate farmer suicides in the larger context of the agrarian crisis in India, based on our field work in the Vidarbha region of Maharashtra. Once Vidarbha was known for its cotton or "white gold" production, but now the region is mostly known as the suicide belt of India. The situation is the same in the nearby region of Vidarbha. Even a debt of 10,000 rupees $(\$ 150)$ is enough to push a farmer over the edge. Young farmers aged between 18 and 30 accounted for the second-highest number of suicides, leaving widows and children to cope with the consequences (NCRB, 2015).

The objective of the study is firstly, to explore the research question "Do different sources of credit availed by the farmer impact differently on farmer suicide?" and secondly "What are the reasons which are driving the farmers to borrow money from banks followed by private money lenders and again resorting to banks for fulfilment of their credit needs? And also to examine whether the Bankers have any role in motivating farmers to take second loan." The later phenomena were observed during the field study. In the first section, we outline the overall distress happening in the context of India's agriculture, as ascertained from reading various government reports and surveys. In the subsequent sections, we present observations 
from the fieldwork conducted in the Amravati and Yavatmal district of Maharashtra and analyse the preconceived dissimilarities and observed similarities in these two zones. Drawing connections between farmer suicides, outstanding debt from a particular source. Our narrative approach emphasises the kinship dimension of indebtedness, which creates a greater social and moral obligation to repay loans that are borrowed from Formal Financial Institutions failing to which the farmers in order to avoid the shame of debt commits suicide. For convenience of reading and understanding of the interview a note has been attached in the annexure which describes the local terms. The overall purpose of this paper is to explore and analyse the effect of sources of credit causing farmers' distress and why are the farmers compelling themselves to borrow money after taking loan from formal source of credit with reference to the state of Maharashtra.

\section{Review of Literature}

Today, agriculture does not appear to significantly support growth in Indian non-agricultural sectors, neither through capital transfers nor through the creation of a major rural market for industrial produce (Lerche 2013). The Indian agriculture has come a long way since the inception of its planning in the year 1951. The best known study of the impact of formal rural credit in the context of India is by Binswanger and Khandkher (1992) who found that rural credit has a measurable positive effect on agricultural output. Dongre and Deshmukh 2012 conducted a study in the Vidarbha region of Maharashtra and found indebtedness as a major cause of farmer suicide, but do not explore the role of credit. Few more studies conducted by Gruere and Sengupta 2011, Mishra 2006a, Mishra 2006b, Mishra 2006c , Mishra 2006d, found a strong positive correlation between unpaid bank loans and those who have committed suicide. Sadanandan 2014 showed that there is a sharp decline in the percentage of total bank 
loans to agriculture after 1989. While studies of Sarangi et al. 2010 and Dongre \& Deshmukh 2012, all observed the fall in presence of formal sources of finance thus leading the farmers to borrow loans from non-institutional sources, such as local moneylenders.

High debt and over-reliance on money lenders along with more competition between foreign and private banks have been found to be the significant factors behind farmer's death due to suicides in certain states across India (Sadanandan, 2014).

There is a difference between domestic commercial banks and foreign banks in the quantum of lending to the priority sectors. While $40 \%$ of the total deposits must be extended to priority sectors out of which $18 \%$ particularly to agriculture sector by domestic banks, foreign banks have the target of extending only $32 \%$ and that too without a mandatory target to extend to the agriculture sector. Even though there is a rise in the number of branches in the rural areas and the availability of credit is becoming easier, farmer distress is also rising at the same time. Few researchers also studied that the formal financial institutions are not very transparent with their documentation process for the crop loans (Hulme 2000; Mitra \& Shroff 2007; Rhyne 2001; Shylendra 2006). There is an issue of lack of transparency concerning the practices as well as terms and conditions of agriculture loan amongst banks and micro finance institutions. Besides, they resort to devious means of loan recovery such as confiscating title deeds, using intimidation and abusive language and combining multiple products like savings, insurance, and loan to ensure prompt recovery (ibid). With the expansion of formal institution, for example, multiple borrowing became a common strategy of households who used newly available credit from varied sources including MFIs, SHGs, and moneylenders to sustain consumption while paying off old debts. This created a cycle of escalating indebtedness that continuously contained the possibility of a financial implosion in the face of external shocks such as illness, crop failure or an economic downturn (Taylor 2012). 
Apart from agriculture needs the farmer's needs money also to meet social needs (Singh, 2006). The study showed that the farmers in rural India spend too much on non-productive (consumption) purposes like healthcare, death and marriage ceremonies, etc. Gill and Singh 2006 in their research study showed that the non-availability of consumption loans from formal institutions pushes the farmers to use productive loans for consumption purposes. A classic example of the above-mentioned phenomena is the bank loan funded new tractors being disposed of in second-hand markets immediately after purchase to arrange cash for other family needs like marriages, paying off old debts, etc. (Singh 2006, Singh et al. 2016). Datta et al. 2018 also conducted a primary-level household survey in the Telangana State of India, and the objective of the study was to identify the factors that impacted indebtedness of a household and the purposes for which the loans were utilized. Results of their study showed that among all explanatory variables, principal occupation, and use of modern technology, the rate of interest, household medical expenditure, and source of the loan were significant, indicating that these variables significantly affected the loan taken by the farmers in the study area.

Datta et al. (2018) conducted a primary-level household survey in Telangana. Bayesian and Lasso regression methods were used to identify the factors that impacted the indebtedness of a household and the purposes for which the loans were utilized. Results show that among all explanatory variables, principal occupation, and use of modern technology, the rate of interest, household medical expenditure, and source of the loan were significant, indicating that these variables significantly affected the loan taken by the farmers in the study area. The study suggested that alternative sources of non-farm income and promotion of modern technology in agriculture could reduce farmers' 
Past studies related to farmers' suicide due to indebtedness mainly attributed to taking a loan from money lenders, Annexure-Table 1

While all the studies mentioned in Table 1 posed a finger on the money lenders for the extreme distress among the farmers in India, the task force on credit-related issues of farmers set up by Ministry of agriculture in India found that still the people in rural India are relying on money lender, and their percentage has increased from $18 \%$ to $27 \%$ (Sarangi et al. 2015). Some segments of agrarian society were able to use access to finance to support consumption or diversify livelihoods, others have become caught in escalating debt traps that brutally expose the limits to fighting poverty through the proliferation of credit (Taylor 2011). This posed a serious question - if the money lenders are at fault then why the rural population is still dependent on them.

The present study is to meet this gap in the existing body of knowledge on the issue of farmers' suicide and the role of sources of credit.

\section{Research Design}

Mixed Methods research that involves collecting, analyzing and integrating quantitative and qualitative research data has been adopted in this study. It is thus a blend of methodologies in the study of the same phenomenon (Webb et al., 1999; Jick 1979; Johnson \& Onwuegbuzie 2007). Conceding to the fact that all methods have limitations, mixed method mutually neutralizes biases arising from each other (Jick 1979; Creswell, 2009). Thus, the results of both methods can reinforce each other (Creswell et al. 2011).

Since the study involved multiple stages of data collection, mixed method research provided a greater breadth of perspectives around the issue of which sources of credit is creating extreme distress among farmers and why farmers are forcing themselves in borrowing money from 
multiple sources. Mix method also helps in correctly interpreting the findings where the researchers are not much familiar with the local language. Mixed Method help the researchers to define more nebulous concepts and lend itself well to outcome driven research. Thus the researcher did not incline themselves in either pure qualitative study or a pure quantitative study. While the quantitative method in this study involved a detailed survey wherein descriptive statistics have been used to draw results; while qualitative methods included Focus Group Discussions (FGDs) and in-depth interviews through One-on-One Interaction and Observation. In-depth interviews also allowed the researcher to explore complex or contradictory matters. In contrast to ordinary conversations, in-depth interviews method helped in focusing on the research question and pursue it in great depth. (Rubin and Rubin, 2012). Thus we employed the in-depth interview technique to collect data as one of the major mechanisms of collecting data.

In this research, we adopted semi-structured in-depth interview method, wherein each interviewee was asked similar questions under the main heads. The interview was based on an interview guide which contained different questions covering different aspects of the agrarian crisis, credit facility, difficulties faced by them in getting credit, reasons for choosing alternative finance and also going for loan multiple numbers of times, etc. Each aspect was covered by asking one or more questions and using a variety of probes and converses (Onwuegbuzie \& Leech 2006), until the inquiry has satisfied the research objectives. Semistructured in-depth interviews were kept flexible and the interviewer could modify the order and details of how topics need to be covered, but because respondents are asked more or less the same questions this makes comparisons across interviews, possible. (Onwuegbuzie \& Teddie 2003). 
Focus group discussions were conducted among the different stake holders to discuss what people felt about this issues and also to get a group dynamic. A total of three FGDs were conducted. There were five to eight participants per FGD. The group consisted of people from NABARD, local branch manager, the victim, and non-victim household representatives, Gram Panchayat and Tehsildar. The FGDs entailed listing of the focus groups and participants; arrangement of dates and logistics, when required; creation of the check list; skilled facilitation and use of tape recorders and taking field notes.

An FGD was conducted, and major themes were identified from the inputs obtained during FGD. In-depth interviews were carried out focusing on these themes. Codes were prepared by a collection of words, segment, sentence(s) or paragraph(s) which represented the spirit or core attribute of verbal information and this helped the researcher to categorize data. The process of scrutiny or re-examining this open coding helped the researcher in identifying the data and in moving towards selective coding which highlighted the themes that the researcher wanted to achieve through the research objective. This process helped in a detailed understanding of the data. Flexibility in refining code structure helped the researcher to encompass more ideas, or merge new ideas into existing codes or split into additional new codes.

\section{$\underline{\text { Tool Development }}$}

A questionnaire was developed for the purpose of gathering quantitative data from the respondents. Keeping in view the outcome, Questionnaire included both open and closed-ended questions. Open formats encouraged the candid expression of the respondent in a free-flowing manner, and thus create an insightful angle to the study. Closed formats limit the responses to given options, which allows easy statistical calculations and ease of analysis. The interview schedule was created with different questions under main heads to capture the depth of the 
matter. The conglomerate of tools was created to be able to touch base with the research objective. The FGD Check List was also created for easy moderation and execution.

\section{$\underline{\text { Data Collection and Sampling Procedure }}$}

This study is based on both primary as well as secondary data sources. The secondary data on various parameters related to bank agriculture credit, different schemes available for farmers in Maharashtra and other related issues were collected from the publications of National Bank for Agriculture and Rural Development (NABARD), Mumbai and State Government of Maharashtra. The Secondary Data used in this study were collected in person from State Crime Record Bureau, Mumbai offices.

\section{Selection of the Study Area - Maharashtra: An anomaly of Opulence \& Paucity}

In India, Maharashtra contributes highest to the GDP besides being the most industrialized state (census, 2011). Headquarters of various corporates and financial institutions are situated in Mumbai which is the state capital of Maharashtra as well as the financial capital of India. Mumbai also houses main stock market and commodity exchanges of India. According to the 2011 Census a total literacy rate of 82.34 (male $88.38 \%$ and female $75.87 \%$ ) against 74.04 percent at the national level but still Maharashtra has some of the poorest and most underdeveloped regions in the country.

Maharashtra also leads the country in the number of farmer suicides. According to the NCRB 2015 report, the state has recorded the highest number of farmer suicides (total of 2835). Table 2 attached in the Annexure shows the total farmer suicide across the six administrative divisions of Maharashtra over the last fifteen years. The Amravati region alone accounted for the highest suicide rate in the past fifteen years with an astounding figure of 11981 suicides. Thus, the researcher chose the Amravati Division as the study Universe. Amravati division is further divided into six Talukas which includes Yavatmal, Akola, Amravati, Buldhana, Wardha 
and Washim, Annexure table 3. Table 3 shows the total farmer suicide that has occurred in the different talukas under the Amravati division. The researchers selected Amravati and Yavatmal talukas as their sample frame since these two Taluka's showed the highest number of farmer suicide over the decade.

\section{Sampling Procedure}

The current research is applied social research, and there was a circumstance where it was not feasible, practically or theoretically to do random sampling thus we consider nonprobabilistic sampling technique for selecting the suicide victim household and random sampling for choosing the non-suicide victim household. Samples in the study were selected based on availability or ease of inclusion of the participants. This type of sampling is also known as Accidental Sampling. A list of farmers who had committed suicide due to indebtedness and had received government compensation was obtained for both the Talukas namely Amravati and Yavatmal from the Chief Ministers Office in Mumbai. This was the sample frame. The list contained the name, address, relatives survived by and contact details of all the suicide victims. The researchers had to get the permission of the District Collector and the Village Panchayat before entering the villages to collect data for the research. The Village Panchayat also provided the researcher with a list of households who had taken a loan from different banks apart from those who had committed suicide. Personally, the researchers contacted the relatives of these suicide victims over the phone, and only 25 suicide victim households out of 350 agreed to give an in-depth interview to the researchers. It may be mentioned here that we reached data saturation by 15 interviews. These households were scattered in different villages of the respective talukas. 80 nonsuicide victim households were selected randomly from the list provided by the respective Village Panchayat. From the 80, 25 participants were selected, to have the same sample size from suicide and non-suicide groups, randomly who also agreed to give an interview. The researcher(s) pre-informed the participants and took their consent 
for recording of the interview and they were informed that it would be strictly used for the research purpose and confidentiality would be maintained. The field study was carried over a period of six to seven months.

\section{Reliability \& Validity of the tool}

Reliability is the ability of this scale to produce consistent results. For the current study reliability was assessed by using test-retest method. In the test-retest method, reliability is examined by administrating the same set of respondents on two different occasions. The two set of responses are then correlated to study the consistency in responses on the two occasions. Since the variables in the study were categorical variable Phi \& Cramer's V was used to study the consistency of the scale (Golafshani, 2003). Phi and Cramer's V value above 0.5 indicates reliability (Golafshani, 2003). Phi \& crammer's value for almost all variables is above 0.5. Hence the Reliability of the tool was supported.

Validity was assessed using face validity. Face validity is a subjective way of assessing the validity of the instrument. Five experts were approached and asked to comment on the instrument regarding the ability of the instrument in measuring the underlined variable. A 3point scale $(1=$ Do not measure the underline variable, $2=$ moderately/ somewhat measure the underline variable, $3=$ completely measure the underline variable.) Data was gathered through the five experts were analyzed using descriptive statistics. Mean values for all the variable were more than 2.5 on a 3-point scale. Hence for all the variables experts agreed that the instruments measure the underline variable correctly. Hence validity was supported.

For reliability and validity of the qualitative study no separate test was conducted as “Researcher's reflexivity (and subsequent writing-up transparency) throughout the whole research process checked the reliability and validity of the in depth interviews conducted" (Golafshani, 2003) 


\section{Results}

The descriptive statistics, presented in table 4 , helps the researcher in portraying a clear pic nature about the sample households who had borrowed money from different sources of credit and it also helped in partial answering of the research question is there any link between sources of credit and farmer distress in the Amravati and Yavatmal region of Maharashtra, India.

Table 4: Suicide Status * Sources of Loan

\begin{tabular}{|c|c|c|c|c|c|}
\hline & & $\begin{array}{l}\text { Formal } \\
\text { Source } \\
\end{array}$ & $\begin{array}{c}\text { Informal } \\
\text { Source }\end{array}$ & $\begin{array}{c}\text { Both } \\
\text { Formal \& } \\
\text { Informal } \\
\text { Source } \\
\end{array}$ & TOTAL \\
\hline \multirow{2}{*}{$\begin{array}{l}\text { Credit availed and } \\
\text { committed suicide }\end{array}$} & Count & 11 & 4 & 10 & 25 \\
\hline & $\%$ within & $44 \%$ & $16 \%$ & $40 \%$ & $100 \%$ \\
\hline \multirow{2}{*}{$\begin{array}{l}\text { Credit availed and did } \\
\text { not commit suicide }\end{array}$} & Count & 1 & 16 & 8 & 25 \\
\hline & $\%$ within & $4 \%$ & $64 \%$ & $32 \%$ & $100 \%$ \\
\hline \multirow{2}{*}{ TOTAL } & Count & 12 & 20 & 18 & 50 \\
\hline & $\%$ within & $24 \%$ & $40 \%$ & $36 \%$ & $100 \%$ \\
\hline
\end{tabular}

From the descriptive statistics, it can be seen that out of the 25 farmers who have committed suicide, $44 \%$ have borrowed loan from formal sources of credit available, $16 \%$ from the informal source of credit available and $40 \%$ have borrowed loan from both the formal and informal sources of credit. A similar in-depth interview was conducted for families who have availed loan from different sources of credit but had no signs of suicide. It was found that out of 25 families from non-suicidal households $64 \%$ borrowed loan from informal sources, $4 \%$ borrowed loan from formal sources and $32 \%$ borrowed loan from both the sources. Hence it can be seen that the percentage of suicide is more in case of farmers who are availing loan either from formal source or a combination of both the sources. This partially answers the research question that had arisen in the minds of the researchers after doing the field study and reading the various contradictory government reports.

The excerpts of some interviews are presented below.

During the field interaction, a farmer named Arun Bhise (Name changed) aged 45 years and is metric passed from a district school in the Yavatmal region shared his experience about the nightmare he faced for a crop loan of rupees eighty thousand - 
"Oh!!! Bank Loan!!!!!!!!!! You want to know my experience about the bank loan (looked angry and pained) For a crop loan for rupees ninety thousand I almost went to bank ten to twelve times The manager was newly posted and was also not aware himself about what all documents are required...... every time I went he demanded a new document and based on it he kept on postponing the whole process.............they do all these things to get some undue advantages ........ The sowing season was almost to end when I received the money, that too only sixty-five thousand (Smirked) The manager does not know even our local language and is very rude. At last the cropping season was about to end so to meet my immediate need I went to the local sahukar of the village and borrowed money."

After listening to the whole event the investigators wanted to know the details of the loan he took from the money lender. Thus the interview is continued below -

Interviewer: Do you know the terms and conditions of the loan you took from the money lender?

Respondent: "I wanted money at the time of need, and he provided me. He is also from amongst us.................. He understands my economic condition and also empathizes with me........ If I become a defaulter, he takes away the land and gives me a job opportunity so that I can survive with it....... (Sorrow in the face).

Interviewer: Could not follow your statement.......... gives job opportunity?

Respondent: "Yes...... I mean we work as agriculture labourer in filed and get daily wages..... He is also powerful ...... so many a times he gets us enrolled under some scheme of the government to earn money....."...... Your newspaper and government say that the loans from money lenders are responsible for the suicide of my fellow brothers who committed suicide but the reality is they help us at the time of need ....... We are very well aware that the interest charged is more than any financial institution but...................... Angry face).....These banks are responsible for our situation. Had they done their job properly we would never have to go to any sahukars.... 
Another interview was given by Ravi Burhade (name changed) who lost his elder brother to this crisis stated .....

“....................Ramaji (Name Changed)is the name of my brother whom I lost .(silent and tears in eyes), he was just 35 years old farmer and committed suicide on 26-06-2016 at village Januna, Amravati district by taking poison. We owned a total of 2 acres of land, and main crops grown by us was just cotton \& soybean. My very old parents and unmarried sister and I am only there in the family.

My brother had applied for a loan of Rs.80000, and the bank granted a loan of Rs.60000. He purchased pesticides, insecticides, seeds of Rs.75000/-from a local shopkeeper. To meet the deficit of Rs. 15000 he had borrowed money from the private money lender. The year 20152016 turned out to be the drought year, and he was not able to recover any expense. This created pressure on him. There was constant pressure by the bank on him for repayment of the loan. The Manager kept visiting my house and insulted the family for repayment ..............This situation led him to commit suicide. “

Respondent: Did the money lender did not put any pressure on you or your brother to repay the loan?

"(Smirks) why do you think he will do so? They are understanding ..... he knows I am not a fraud and will repay him if I had money banks think us to be cheat.... My sahukar bhau said need not to worry about payment, and I can pay him back when I receive my compensation from the government ...I will repay him when government clears all my loans...."

Thus through these interviews, we can easily conclude that one of the main reason for farmer distress in this region is the indebtedness among the farmers and the moneylenders are not the only source of the problem of creating extreme farmer distress instead they extend a helping hand in the time of need. Through the interview, it was also noticed that the bankers often do 
not empathize with the situation and their harsh behavior towards the farmers for loan recovery often leads to falling in social status and acts as a catalyst in promoting farmer suicide.

To be sure that this is not a statement we have received during the in-depth field interview by chance the researchers re validated it using few statistical tools, whose results are depicted below.

\section{$\underline{\text { Variables and Measurement }}$}

Famers Committing suicide is measured using a dichotomous scale $1=$ Committed suicide $2=$ Did not commit suicide. Sources of Loan is a categorical variable with three options $(1=$ Formal Source, 2= Informal Source \& 3= Both Formal and Informal Source).

\section{Statistical Tests: Chi-square test of Contingency}

H0: Farmer suicide is independent of the Sources of Credit

H1: Farmer suicide is dependent of the Sources of Credit

Level of Significance: $\alpha=0.05$

\begin{tabular}{|c|c|c|}
\hline $\begin{array}{c}\text { Chi-Square } \\
\text { Tests }\end{array}$ & & \\
\hline & Value & df \\
\hline Pearson Chi-Square & $15.756^{\mathrm{a}}$ & 2 \\
\hline Likelihood Ratio & 17.684 & 2 \\
\hline Linear-by-Linear Association & 2.142 & 1 \\
\hline $\mathrm{N}$ of Valid Cases & 50 & \\
\hline
\end{tabular}

Since the p-value (0.000) is less than the level of significance $(0.05)$, the null hypothesis is rejected. Hence it is concluded that farmers. Suicide depends upon the sources of credit. Thus it could be seen that the results of the qualitative study and quantitative study were complementing one another and the findings have answered the research question. This motivated the researchers to move a step ahead and now investigate the second research question which enquired what the reasons are driving the farmers to borrow money from banks followed by private money lenders and again resorting to banks for fulfillment of their credit needs for the same set of farmers.

The excerpts of the interview are appended below: 
Interviewer: Do you have a loan?

Respondent: (Arrogantly laughs).... Can u even imagine a farmers life without loan......... have two loans outstanding from formal institution and one from Sahukar Dada

Interviewer: Which source of credit did you use first to borrow money and why did you choose that particular source?

Respondent: In the past, you can see I have always borrowed money just before the sowing season from the bank................ getting a loan from the bank was again a challenge...... I was granted loan by the bank mid of the sowing season. ................. I had taken bank loan as the rate of interest was subsidized.

Interviewer: Did you repay the bank loan after the crop was ready for the market?

Respondent: NO... The cropping season was declared as a drought year, and I suffered an immense loss............ I worked as labour in my field. ... I invested money in the filed for getting best pesticide, seeds all went in vain. I had no money even to feed my family how do you think I would have repaid the bank? Interviewer: How did you survive during that time? I mean how did you run the family? Respondent I could not even sell my land as I had taken a loan from the bank on it ...................... took a loan from the Sahukar dada .......Loan waiver was declared but when it would be executed was not clear..........I was in the dearth need of money..................was looking out for immediate relief

Interviewer: Didn't you go to the bank and ask about the loan waiver or another loan?

Respondent: .................The manger did not give me immediately another loan as I bad credit history........yes but he suggested me an idea to get a fresh loan he told me that if I repay even $25 \%$ of the existing loan I would be removed from the NPA category and would be eligible for next loan as my existing loan would be converted in long-term loan. 
Interviewer: What did you do after hearing this from the manager?

Respondent: (Silence) I fell in his trap. the money $I$ had borrowed from Sahukar Dada I gave it almost in the bank and got a new loan...... but I never knew what a grave mistake I did. I did not get a loan waiver as I had made payment and in return, the loan amount started mounting on me as the rate of interest had also increased in the new scheme. I fell in the trap....

Buying expensive seeds and other agricultural inputs through loans with high interest means that stress begins to mount at the very beginning of the crop cycle. Through this, we can conclude that mounting loan amount, piled up interest from different sources, with deteriorate family conditions results in sustained mental stress which pushes some farmer to commit suicide.

During the field visit the researchers got a chance to interview one of the bankers on the agrarian crisis, and on crop loan, an excerpt of the same is appended below:

Interviewer: What motivates you to give crop loan to the farmers?

Respondent: .............It is my job to give a loan to eligible borrowers and more over we bound by the RBI circular on lending new priority sector lending norms set by RBI has strictly instructed us to give loan and meet the target. .If I don't meet the target of lending, I will be issued a memo from the zonal office. Interviewer: In spite of knowing the credit history and capability you still give them loan? Are you not bothered how they will repay?

Respondent See madam I have a target to meet, and I too know they don't have the capacity to repay so I tell them to pay at least little so that you will not become NPA and get another loan..................Both the parties are gaining this way...........the farmer is getting money, and I am meeting my set target of loan disbursal. ...Yes..........one more thing everyone is happy till they get their share of pie......(Smirks) 
Thus through these interviews we can conclude that the farmers are going to informal source after taking the first loan from a bank as the loan they get are inadequate to meet their need and another reason is the over marketing (predatory lending?) by the bankers to take loans in order to meet their target of priority sector lending. And it is also evident from the interview responses that the revised terms and conditions due to the conversion of a loan from short term to long term agricultural loan are not properly explained to the farmers.

\section{Discussion}

Through the field study, we conducted interviews for the family members of the deceased farmer (see results section) and concluded that an Indian farmer in a particular cropping season wears three hats simultaneously: those of an investor, labourer, and farmer. The farmer also represents himself as an entrepreneur, often bringing in inherited land holding (or working as a tenant farmer) and traditional knowledge. The farmer runs the harvest cycle but makes little to no profit. As a labourer, farmer and their family members often represent the underemployed, underpaid resource that works for almost free. In these two roles, it is evident that the farmer represents the aspects of management and labour involved in an enterprise. However, these aspects largely do not push the farmer to commit suicide.

Farmers are more often pushed to take their own lives in their roles as investors, due to agrarian distress and lack of business viability. Loans mount, interest climbs steeply, and the resulting sustained mental stress pushes some farmer-investors to commit suicide. Farmers ought not to wear the hat of investors, given the mismatch between their meager resources and the high-risk factor.

The Indian bankers often lack empathy and are so target bound (evident from the interview, attached in results section) that they forget the farmer's pain and lure him to take a loan. Again 
to avoid NPA, harsh recovery mechanisms are used against these farmers. All this creates a mental pressure and social pressure too, to avoid this the farmer takes his life.

\section{5a. Theoretical Implications}

It has been observed from the extant literature and the field study that agricultural credit plays a vital role in supporting agricultural production in India. The results of the study have found that the outreach of agricultural credit has increased over the years but at the same time several weaknesses have crept in which have affected the viability and sustainability of these institutions

Yes, it is true that indebtedness is a problem, but why do farmers in India suffer such debt need a nuanced look. The farmers are taking a loan from multiple sources like the formal source of credit as well as an informal source of credit. The multiple borrowing by the farmers due to various reasons like antiquated legal framework, the outdated tenancy laws, marriage in the family, medical needs of the family, etc. create an interaction effect which worsens the situation. The multiple borrowing creates a debt trap which forces the farmers to commit suicide to escape the social shame. Thus, the findings of the study contribute to knowing the new theory of "Multiple Borrowing Interaction Theory." This theory will imply finding the root cause for farmer distress and also in addressing the larger issues like distorted socioeconomic policy and complicated credit system of the country.

\section{5b. Practical Implication}

Successive governments have focused more on control rather than prevention. Through the theoretical contribution of this study, the policy makers will get an over view that it will take more than short-term measures and disproportionately implemented programs to wade through the crisis.. This study will help the policy makers in identifying the root cause of farmers being in debt and reorientation of the existing policies. One of the major findings of the study was the harsh recovery mechanism adopted by the formal institutions in order to avoid the defaults. The study will also help the policy makers in sensitizing the loan disbursing officers.

\section{Conclusion}

Abject poverty, high levels of indebtedness and pressure to repay loans borrowed from formal financial institutions are the leading causes behind farmer suicides in this region of Maharashtra. Almost every farm household has debts, and a large number of them have 
accumulated such debts over the years. Till date, the extant literature was attributing extreme farmer distress to the high-interest rate charged by local moneylenders. But government data and the field study establish that loan from Bank-informal Source-Bank is the major reason for the farmer suicide. The study also establishes the reason for taking a loan from money lenders after taking a loan from the bank and there after again going back to the bank resulting in a debt trap situation. The current research also found that moneylenders were more flexible compared to banks and microfinance institutions. The formal financial institution is less flexible with their rules and regulations of loan disbursement as well as loan recovery because their set rules don't permit them flexibility. They create social pressure for repayment by telling others in the vicinity. This leads to a fall in the status of the farmer in the society and to escape this shame he commits suicide. Thus the need of the hour is to address that despite an extensive existing credit market the farmers are still borrowing from the private money lenders and are approaching banks only when the doors of private money lenders are closing.

It may be concluded that the present research meets the gap in the existing literature on this subject.

\section{Reference}

Behere, P.B. and A.P. Behere. 2008. "Farmers' Suicide in Vidarbha Region of Maharashtra State: A Myth or Reality?” Indian Journal of Psychiatry 50(2): 124-127.

Chhikara, K. S., \& Kodan, A. S. (2014). Farmers' Indebtedness in Haryana: A Study. Journal of Rural Development, 32(4), 347-365.

Creswell, J. W. (2009). Mapping the field of mixed methods research.

Creswell, J. W., Klassen, A. C., Plano Clark, V. L., \& Smith, K. C. (2011). Best practices for mixed methods research in the health sciences. Bethesda (Maryland): National Institutes of Health, 2013, 541-545. 
Datta, S., Tiwari, A. K., \& Shylajan, C. S. (2018). An empirical analysis of nature, magnitude and determinants of farmers' indebtedness in India. International Journal of Social Economics, 45(6), 888-908

Dongre, A. R., \& Deshmukh, P. R. (2012). Farmers' suicides in the Vidarbha region of Maharashtra, India: a qualitative exploration of their causes. Journal of Injury and Violence research, 4(1), 2.

Kannan, E. (2015). Trends in Agricultural Incomes: An Analysis at the Select Crop and State Levels in India. Journal of Agrarian Change, 15(2), 201-219.

Gedela, S. P. R., \& Prakasa, R. (2008). Factors responsible for agrarian crisis in Andhra Pradesh (a logistic regression analysis). World Appl Sci J, 4(5), 707-13.

Gill, Anita, Lakhwinder Singh, (2006), Farmers' Suicides and Response of Public Policy Evidence, Diagnosis and Alternatives from Punjab, Economic Political Weekly.

Golafshani, N. (2003). Understanding reliability and validity in qualitative research. The qualitative report, 8(4), 597-606.

Gruère, G., \& Sengupta, D. (2011). Bt cotton and farmer suicides in India: An evidence-based assessment. The journal of development studies, 47(2), 316-337.

Hulme, D. (2000). Is microdebt good for poor people? A note on the dark side of microfinance. Small Enterprise Development, 11(1), 26-28.

Jick, T. D. (1979). Mixing qualitative and quantitative methods: Triangulation in action. Administrative science quarterly, 24(4), 602-611.

Johnson, R. B., Onwuegbuzie, A. J., \& Turner, L. A. (2007). Toward a definition of mixed methods research. Journal of mixed methods research, 1(2), 112-133.

Kale, N. M. (2011). Productivity, annual income and indebtedness position: a comparative study of farmers who committed suicides with others. Karnataka Journal of Agricultural Sciences, 24(3).

Kale, N.M., D.M. Mankar, and P.P. Wankhade. 2014. "Factors Affecting the Agrarian Distress Proneness in Vidarbha.” Global Journal of Science Frontier Research: D. Agriculture and Veterinary 14(10).

Khandker, S. R., \& Binswanger, H. C. (1992). The impact of formal finance on the rural economy of India. World Bank. 
Lerche, J. (2013). The Agrarian Question in Neoliberal India: Agrarian Transition Bypassed? Journal of Agrarian Change, 13(3), 382-404.

Mishra, Srijit. 2006a. "Farmers' Suicides in Maharashtra." Economic and Political Weekly 41(16): 1538-1545.

Mishra, Srijit. 2006b. "Suicide Mortality Rates across States of India, 1975-2001: A Statistical Note.” Economic and Political Weekly 41(16): 1566-1569.

Mishra, Srijit. 2006c. Suicide of Farmers in Maharashtra (Submitted to the Government of Maharashtra). Mumbai: Indira Gandhi Institute of Development Research.

Mishra, Srijit. 2006d. "Farmers' Suicides in Maharashtra: Content Analysis of Media Reports." In Suicide of Farmers in Maharashtra (Submitted to the Government of Maharashtra), edited by Mishra, Srijit, Sangeeta Shroff, Deepak Shah, Vivek Deshpande, Anjali P. Kulkarni, Vinayak S. Deshpande, and P.R. Bhatkule, 5-24. Mumbai: Indira Gandhi Institute of Development Research.

Mitra, S., \& Shroff, S. (2007). Farmers' suicides in Maharashtra. Economic and Political Weekly, 73-77.

Onwuegbuzie, A. J., \& Leech, N. L. (2006). Linking research questions to mixed methods data analysis procedures 1 . The qualitative report, 11(3), 474-498.

Onwuegbuzie, A. J., \& Teddlie, C. (2003). A framework for analysing data in mixed methods research. Handbook of mixed methods in social and behavioural research, 2, 397-430.

Rhyne, E. (2001). Mainstreaming microfinance: How lending to the poor began, grew, and came of age in Bolivia (No. 332.1 R4.). Bloomfield, CT: Kumarian Press.

Sadanandan, Anoop. 2014. Political economy of suicide: Financial reforms, credit crunches and farmer suicides in India. The journal of developing areas 48, (4): 287-307.

Shylendra, H. S. (2006). Microfinance institutions in Andhra Pradesh: crisis and diagnosis. Economic and Political Weekly, 1959-1963.

Singh, L., Bhangoo, K. S., \& Sharma, R. (2016). Agrarian distress and farmer suicides in north India. Routledge.

Singh, Sukhpal, (2006), Credit, Indebtedness and Farmer Suicides in Punjab: Some Missing Links, Economic Political Weekly 41(30). 
Taylor, M. (2011). 'Freedom from poverty is not for free': rural development and the microfinance crisis in Andhra Pradesh, India. Journal of Agrarian Change, 11(4), 484504.

Taylor, M. (2012). The Antinomies of 'Financial Inclusion': Debt, Distress and the Workings of Indian Microfinance. Journal of Agrarian Change, 12(4), 601-610.

U.C. Sarangi, K.V. Eapen, D. Singh, R.K. Tiwari, N.B. Patil, R. ChatterjeeReport of the task force on credit related issues of farmers Ministry of Agriculture, Government of India (2010) available at: $\quad \underline{\text { http://indiamicrofinance.com/wp }}$ content/uploads/2010/12/nabard-taskfore-report-farmers-credit.pdf.

Webb, E. J., Campbell, D. T., Schwartz, R. D., \& Sechrest, L. (1999). Unobtrusive measures (Vol. 2). Sage Publications. 


\section{Annexure}

Table 1: Studies which identified moneylenders and informal sources of credit responsible for farmer suicide.

\begin{tabular}{|c|c|c|c|}
\hline Author & $\begin{array}{c}\text { Publication } \\
\text { year }\end{array}$ & Description of study & Key results \\
\hline Kale et al & 2014 & $\begin{array}{l}\text { Interview of family } \\
\text { members of } 200 \text { victims in } \\
\text { Vidharbha province }\end{array}$ & $\begin{array}{l}47 \% \text { of the farmers had outstanding } \\
\text { debt to only institutional sources. } \\
\text { - Some } 51.5 \% \text { had outstanding debt } \\
\text { to both institutional and non- } \\
\text { institutional sources. }\end{array}$ \\
\hline $\begin{array}{l}\text { Chhikara } \\
\text { and Kodan }\end{array}$ & 2013 & $\begin{array}{l}\text { Analysis of secondary data } \\
\text { on farmer indebtedness in } \\
\text { Haryana }\end{array}$ & $\begin{array}{l}\text { - Negative association between the } \\
\text { size of the landholding and } \\
\text { percentage of credit obtained from } \\
\text { informal sources } \\
\text { - Some } 29-53 \% \text { of credit for } \\
\text { marginal farmers, } 38 \% \text { for small } \\
\text { farmers, and } 25 \% \text { for large farmers } \\
\text { is from informal sources }\end{array}$ \\
\hline Kale & 2011 & $\begin{array}{l}\text { Small case-control study in } \\
\text { Vidarbha } \\
\text { province ( } 40 \text { cases, } 40 \\
\text { controls) }\end{array}$ & $\begin{array}{l}\text { - Formal sources made up } 76 \% \text { of } \\
\text { victims' credit, but this was } 96 \% \text { in } \\
\text { the non-suicidal group. } \\
\text { - The non-suicidal group was also } \\
\text { much less likely to require credit. }\end{array}$ \\
\hline $\begin{array}{l}\text { Behere and } \\
\text { Behere }\end{array}$ & 2008 & $\begin{array}{l}\text { Report on farmers' suicide } \\
\text { in Vidarbha province }\end{array}$ & $\begin{array}{l}\text { - Moneylenders are the } \\
\text { predominant source of loans for } \\
\text { farmers here at } 28.4 \% \text {. } \\
\text { - Only } 3.94 \% \text { access land } \\
\text { development } \\
\text { banks. }\end{array}$ \\
\hline Gedela & 2008 & $\begin{array}{l}\text { Small case-control study in } \\
\text { Andhra Pradesh ( } 37 \text { cases, } \\
37 \text { controls) }\end{array}$ & $\begin{array}{l}\text { - Suicide victims obtain up to } 70 \% \\
\text { of their credit from private } \\
\text { moneylenders. } \\
\text { Households with victims also had } \\
\text { much higher debt. }\end{array}$ \\
\hline
\end{tabular}

Table 2: Division wise number of Farmer Suicides in Maharashtra

\begin{tabular}{|c|c|c|c|c|c|c|c|}
\hline Year & Konkan & Nashik & Pune & Aurangabad & Amravati & Nagpur & Maharashtra \\
\hline $\mathbf{2 0 0 1}$ & 0 & 10 & 0 & 0 & 49 & 3 & 62 \\
\hline $\mathbf{2 0 0 2}$ & 0 & 2 & 1 & 9 & 80 & 30 & 122 \\
\hline $\mathbf{2 0 0 3}$ & 0 & 2 & 3 & 14 & 134 & 27 & 180 \\
\hline $\mathbf{2 0 0 4}$ & 0 & 38 & 9 & 95 & 418 & 80 & 640 \\
\hline $\mathbf{2 0 0 5}$ & 0 & 33 & 19 & 58 & 419 & 80 & 609 \\
\hline
\end{tabular}




\begin{tabular}{|c|c|c|c|c|c|c|c|}
$\mathbf{2 0 0 6}$ & 3 & 212 & 121 & 378 & 1295 & 367 & 2376 \\
\hline $\mathbf{2 0 0 7}$ & 0 & 183 & 123 & 327 & 1119 & 324 & 2076 \\
\hline $\mathbf{2 0 0 8}$ & 2 & 172 & 120 & 285 & 1061 & 326 & 1966 \\
\hline $\mathbf{2 0 0 9}$ & 0 & 125 & 91 & 228 & 905 & 256 & 1605 \\
\hline $\mathbf{2 0 1 0}$ & 4 & 123 & 67 & 191 & 1051 & 305 & 1741 \\
\hline $\mathbf{2 0 1 1}$ & 3 & 172 & 36 & 169 & 886 & 252 & 1518 \\
\hline $\mathbf{2 0 1 2}$ & 4 & 202 & 35 & 198 & 841 & 193 & 1473 \\
\hline $\mathbf{2 0 1 3}$ & 0 & 170 & 37 & 207 & 705 & 177 & 1296 \\
\hline $\mathbf{2 0 1 4}$ & 4 & 283 & 23 & 574 & 828 & 269 & 1981 \\
\hline $\mathbf{2 0 1 5}$ & 2 & 459 & 96 & 1130 & 1179 & 362 & 3228 \\
\hline $\mathbf{2 0 1 6}$ & 0 & 449 & 72 & 985 & 1011 & 318 & 2835 \\
\hline TOTAL & $\mathbf{2 2}$ & $\mathbf{2 6 3 5}$ & $\mathbf{8 5 3}$ & $\mathbf{4 8 4 8}$ & $\mathbf{1 1 9 8 1}$ & $\mathbf{3 3 6 9}$ & $\mathbf{2 3 7 0 8}$ \\
\hline
\end{tabular}

Source : State Crime Record Bureau, Government of Maharashtra, Pune.

Table 3: District wise number of farmer suicide in Maharashtra

\begin{tabular}{|c|c|c|c|c|c|c|c|}
\hline Year & Amravati & Akola & Yavatmal & Buldhana & Washim & Wardha & $\begin{array}{c}\text { Mahar } \\
\text { ashtra }\end{array}$ \\
\hline & 11 & 6 & 17 & 8 & 7 & 3 & 62 \\
$\mathbf{2 0 0 1}$ & $(17.74 \%)$ & $(9.68 \%)$ & $(27.42 \%)$ & $(12.9 \%)$ & $(11.29 \%)$ & $(4.84 \%)$ & \\
\hline & & & & & & 24 & 122 \\
$\mathbf{2 0 0 2}$ & $(16.39 \%)$ & $(5.74 \%)$ & $(31.15 \%)$ & $(7.38 \%)$ & $(4.92 \%)$ & $(19.67 \%$ & \\
\hline & 41 & 21 & 52 & 14 & 6 & 14 & 180 \\
$\mathbf{2 0 0 3}$ & $(22.78 \%)$ & $(11.67 \%)$ & $(28.89 \%)$ & $(7.78 \%)$ & $(3.33 \%)$ & $(7.78 \%)$ & \\
\hline & 101 & 46 & 142 & 85 & 44 & 29 & 640 \\
$\mathbf{2 0 0 4}$ & $(15.78 \%)$ & $(7.19 \%)$ & $(22.19 \%)$ & $(13.28 \%)$ & $(6.88 \%)$ & $(4.53 \%)$ & \\
\hline & 102 & 43 & 167 & 81 & 26 & 26 & 609 \\
$\mathbf{2 0 0 5}$ & $(16.75 \%)$ & $(7.06)$ & $(27.42 \%)$ & $(13.3 \%)$ & $(4.27 \%)$ & $(4.27 \%)$ & \\
\hline & 270 & 174 & 360 & 306 & 185 & 154 & 2376 \\
$\mathbf{2 0 0 6}$ & $(11.36 \%)$ & $(7.32 \%)$ & $(15.15 \%)$ & $(12.88 \%)$ & $(7.79 \%)$ & $(6.48 \%)$ & \\
\hline & 265 & 125 & 359 & 193 & 177 & 128 & 2076 \\
$\mathbf{2 0 0 7}$ & $(12.75 \%)$ & $(6.02 \%)$ & $(17.29 \%)$ & $(9.3 \%)$ & $(8.53 \%)$ & $(6.17 \%)$ & \\
\hline & 264 & 165 & 311 & 195 & 126 & 87 & 1966 \\
$\mathbf{2 0 0 8}$ & $(13.43 \%)$ & $(8.39 \%)$ & $(15.82 \%)$ & $(9.92 \%)$ & $(6.41 \%)$ & $(4.43 \%)$ & \\
\hline & 220 & 136 & 325 & 103 & 121 & 100 & 1605 \\
$\mathbf{2 0 0 9}$ & $(13.71 \%)$ & $(8.47 \%)$ & $(20.25 \%)$ & $(6.42 \%)$ & $(7.54 \%)$ & $(6.23 \%)$ & \\
\hline & 283 & 200 & 309 & 137 & 122 & 126 & 1741 \\
$\mathbf{2 0 1 0}$ & $(16.26 \%)$ & $(11.49 \%)$ & $(17.75 \%)$ & $(7.87 \%)$ & $(7.01 \%)$ & $(7.24 \%)$ & \\
\hline & 254 & 177 & 240 & 126 & 89 & 113 & 1518 \\
$\mathbf{2 0 1 1}$ & $(16.73 \%)$ & $(11.86 \%)$ & $(15.81 \%)$ & $(8.3 \%)$ & $(5.86 \%)$ & $(7.44 \%)$ & \\
\hline & 190 & 178 & 238 & 153 & 83 & 109 & 1473 \\
$\mathbf{2 0 1 2}$ & $(12.9 \%)$ & $(12.08 \%)$ & $(16.16 \%)$ & $(10.39 \%)$ & $(5.63 \%)$ & $(7.4 \%)$ & \\
\hline & 167 & 136 & 231 & 111 & 60 & 100 & 1296 \\
$\mathbf{2 0 1 3}$ & $(12.89 \%)$ & $(10.49 \%)$ & $(17.82 \%)$ & $(8.65 \%)$ & $(4.63 \%)$ & $(7.72 \%)$ & \\
\hline & 209 & 156 & 266 & 111 & 88 & 134 & 1981 \\
$\mathbf{2 0 1 4}$ & $(10.55 \%)$ & $(7.87 \%)$ & $(13.43 \%)$ & $(5.6 \%)$ & $(4.44 \%)$ & $(6.76 \%)$ & \\
\hline & 306 & 195 & 386 & 189 & 108 & 164 & 3228 \\
$\mathbf{2 0 1 5}$ & $(9.48 \%)$ & $(6.04 \%)$ & $(11.96 \%)$ & $(5.86 \%)$ & $(3.35 \%)$ & $(5.08 \%)$ & \\
\hline & 308 & 148 & 226 & 217 & 89 & 121 & 2835 \\
$\mathbf{2 0 1 6}$ & $(10.86 \%)$ & $(5.22 \%)$ & $(7.97 \%)$ & $(7.65 \%)$ & $(3.14 \%)$ & $(4.27 \%)$ & \\
\hline & & & & & & & \\
\hline
\end{tabular}




\begin{tabular}{|c|c|c|c|c|c|c|c|}
\hline $\begin{array}{c}\text { TOTA } \\
\text { L }\end{array}$ & $\mathbf{3 0 1 1}$ & 1913 & $\mathbf{3 6 6 7}$ & 2038 & 1337 & 1432 & 23708 \\
\hline
\end{tabular}

Note: Figures in bracket are percentage to Maharashtra; Source: Department of Relief and Rehabilitation, Government of Maharashtra.

Table 4: Socio- Economic Profile of Victims

\begin{tabular}{|c|c|c|}
\hline \multicolumn{2}{|c|}{ Total number of victims household surveyed } & \multirow{2}{*}{$\begin{array}{l}25 \\
44 \\
\end{array}$} \\
\hline \multirow{2}{*}{$\begin{array}{l}\text { Type of respondent } \\
\text { (\% to the total sample) }\end{array}$} & 1. Wife/son/Daughter & \\
\hline & 2. Brother/Sister/Others & 56 \\
\hline \multirow{3}{*}{$\begin{array}{c}\text { Gender } \\
(\% \text { to the total sample })\end{array}$} & 1. Male & 94 \\
\hline & 2. Female & 6 \\
\hline & 3. Transgender & $\mathbf{0}$ \\
\hline \multirow{4}{*}{$\begin{array}{c}\text { Social Status } \\
\text { (\% to the total sample) }\end{array}$} & 1. Schedule Caste & 22 \\
\hline & 2. Schedule Tribe & 10 \\
\hline & 3. Other Backward caste & 28 \\
\hline & 4. General & 40 \\
\hline \multirow{4}{*}{$\begin{array}{c}\text { Age group } \\
(\% \text { to the total sample) }\end{array}$} & 1. 18 Years - Below 30 Years & 18 \\
\hline & 2.30 Years -- Below 45 Years & 58 \\
\hline & 3.45 Years - Below 60 Years & 12 \\
\hline & 4.60 Years - Above 60 Years & 10 \\
\hline \multirow{7}{*}{$\begin{array}{l}\text { Years of Schooling } \\
\text { (\% to the total sample) }\end{array}$} & 1. Illiterate & 38 \\
\hline & 2. Primary School & 10 \\
\hline & 3. Middle School & 30 \\
\hline & 4. Matriculation & 8 \\
\hline & 5. Higher Secondary & 10 \\
\hline & 6. Degree/ diploma & $\mathbf{0}$ \\
\hline & 7. Above Degree & 4 \\
\hline \multirow{7}{*}{$\begin{array}{l}\text { Method of Suicide } \\
\text { (\% to the total sample) }\end{array}$} & 1. Poison consumption & 37 \\
\hline & 2. Hanging & 54 \\
\hline & 3. Jumping into river/well & 2 \\
\hline & 4. Current shock & $\mathbf{0}$ \\
\hline & 5.Self immolation & $\mathbf{0}$ \\
\hline & 6.Railway Track & 7 \\
\hline & 7. Others & $\mathbf{0}$ \\
\hline
\end{tabular}

Source: Field Survey

\section{Notes}

NABARD- National Bank for Agriculture and Rural Development (NABARD) is an apex development financial institution in India, headquartered at Mumbai with regional offices all over India. The Bank has been entrusted with "matters concerning policy, planning and operations in the field of credit for agriculture and other economic activities in rural areas in 
India"

GRAM PANCHAYAT It is a village council at the grassroots-level of formalised local selfgovernance system in India and has a sarpanch as its elected head.

TEHSILDAR-In India, the states are divided into districts and each district further subdivided into areas called Tehsils or Taluks. The head of those areas is respectively known as Tehsildar or Talukdar. They also look at the general law and order of their areas and also solve disputes that arise. These officers are also in charge of handing our community certificates to villagers, like a Schedule Tribe certificate.

DISTRICT COLLECTOR-These are the officers who are the head of a district in a state who supervise the overall functioning of the district.

SAHUKARS- a person whose business is lending money, especially at a very high rate of interest to the people in Rural India. They are also known as local money lenders. 